DOI:

UDC 669.136.9

O.G. Cherneta ${ }^{1}, \mathrm{PhD}$, Associate Professor.

V.I. Kubich ${ }^{2}$, Ph.D., Assistant Professor.

M.A. Shcherbina ${ }^{1}, \mathrm{PhD}$, Associate Professor.

V.S. Averyanov ${ }^{1}$, Ph.D., Associate Professor.

D.Z. Shmatko ${ }^{1}$, Ph.D., Associate Professor.

${ }^{1}$ Dniprovsky State Technical University, Kamianske

${ }^{2}$ National University "Zaporizhzhska polytechnika", Zaporizhzhya

\title{
RESEARCH OF STEEL 45 STRUGGING INFLUENCE ON THE PARAMETERS OF ADHESION COMMUNICATION WITH CHROME, CHROME-NICKEL STEEL
}

The results of the microstructure transformation research service steel 45 (fragments of the cam camshaft cam) of the surface layers, which are subjected to modification by boring, are presented in the paper. The graphical dependences of the tangential strength and the coefficient of molecular bond hardening on the contact pressure were obtained for tribological systems of materials "12X2H4 - steel 45", "45XH2MFA - steel 45", "40X - steel 45" in the modeling of shear resistancefriction machine 2 were received. The ambiguous effect of boring on the manifestation of the adhesion bond parameters of the surfaces of the materials under consideration was revealed. face; shear.

Keywords: microstructure; tangential strength; coefficient of hardening; adhesive bond; sur-

В работі наведені результати дослідження трансформації мікроструктури поверхневих шарів експлуатаційної сталі 45 (фрагменти кулачка розподільного валу двигуна), які були оброблені методом борування для модифікування поверхневої структури. Отримані графічні залежності тангениіальної міџності і коефіиієнта зміџнення молекулярного зв'язку від тиску в контакті для трибологічних систем материалів «12X2Н4 - сталь 45», "45ХН2МФА - сталь 45», «40X - сталь 45» при моделюванні ссувного супротиву на машині тертя СМЦ-2. Виявлено неоднозначний влив борування на прояв параметрів адгезійного зв'язку поверхней визначених матеріалів.

Ключеві слова: мікроструктура; тангениіальна міџність; коефіџуієнт зміцнення; адгезійний зв'язок; поверхня; ссув.

\section{Formulation of the problem}

The successful choice of the technique and methods of surface layer processing the machine parts depends to a great extent on the efficiency of the end result - the wear resistance and durability of unit operation, an assembly and a car as a whole. There are many methods of hardening the steel parts surface $[1-5]$ :

The contact interaction of the working surfaces of metals during the transfer and transformation of movements is carried out with friction losses, which are determined by the molecular and mechanical component, determining the parameters of the latter is an urgent scientific and applied task. This is especially concerned surfaces that are modified by alloying elements whose percentage content affects the thermodynamic potential of surface and surface layers. Thus, the expediency of using boron to improve the mechanical properties of medium carbon structural steels has been identified in a number of previous studies.

\section{Formulation of the study purpose}

The purpose of this work is to determine the effect of surface boring of steel 45 on changing the adhesive bond parameters $\tau 0$ and $\beta$ with chromium, chromium-nickel steels with variant hardness of surface layers in shear resistance modeling, where in the first stage it is proposed to perform comparative studies without lubricants. However, information regarding the display of the parameters of the friction molecular component is the shear strength of the adhesive bond $\tau 0$ and the piezoelectric coefficient $\beta$ of the molecular component for tribological systems, such as "steel $45+\mathrm{B} \%-40 \mathrm{X}$ ", 
"steel $45+\mathrm{B} \%$ - 12X2H4", "steel $45+\mathrm{B} \%$ - 45XH2MФA », is currently undefined. These parameters characterize the adhesive properties of the materials. Moreover, since the application of surface technology of boron impregnation turns out the mechanical properties of steel 45 [6-8], the display of the molecular component parameters both in terms of lubrication and without it, when contacted with the surface layers of other metals with variant hardness will have different value. This is necessary, first of all, for the predictive estimation of tribomechanical properties of tribal connections when applying mathematical expressions, which establish the relationship between the friction coefficient and the parameters of the contact microgeometry, the adhesive component, the hardness, the load at the development of plastic, elastic, plastic-elastic deformation areas of friction interaction.

\section{Main material presenting}

Traditionally, the restoration of a worn surface geometry is restored by facing the layer of metal on a pre-prepared surface. The main factor for surface restoration is the strength of the faced surface of the deposited layer with the base material. Therefore, it is very important to fit the surfacing material in such a way as to ensure a secure adhesion of the base material to the substrate, to avoid chips and concentrations of thermal stresses in the transition zones, to have high physical and mechanical characteristics, to be able to strengthen the processing. Figure 1 presents a graphical model of the dependence of the part surface layer hardness from steel 45 , depending on the technological hardening processing methods, on which the dynamics and transformation of the microstructure can clearly observe It depends on the physical and mechanical properties of the workpiece working surface from steel 45. To restore the cam working surface made of steel $45 \mathrm{OZSH}-3$ electrodes with the following chemical composition $(\mathrm{C}-0.4 \%$; $\mathrm{Mn}-0.5 \%$; $\mathrm{Si}-1.9 \%$; $\mathrm{Cr}-9.9 \% ; \mathrm{S}-0.013 \%$; $\mathrm{P}-0.021 \%)$ [8-11] are used. Fig. 1 shows photos of the microstructures of the corresponding zones of the cam sector.

Fig. 1. Photographs of the cam sector microstructures (a. (820), b. (819), b. (818) mid), b (813), b. (819) intersection, sublayer and extreme zone.

Thus, in the transition zone, the residual austenite is transformed into ferrite with the formation of two phases: ferrite particles (dark cascades) and the boron + carbon phase - boron carbide (white inclusions) Fig. 1 c. (818) - fragment of the surface layer zone with increasing $\times 1000$ (819), b (817), and (820) the general structure of the surface layer $\times 1000$ times.

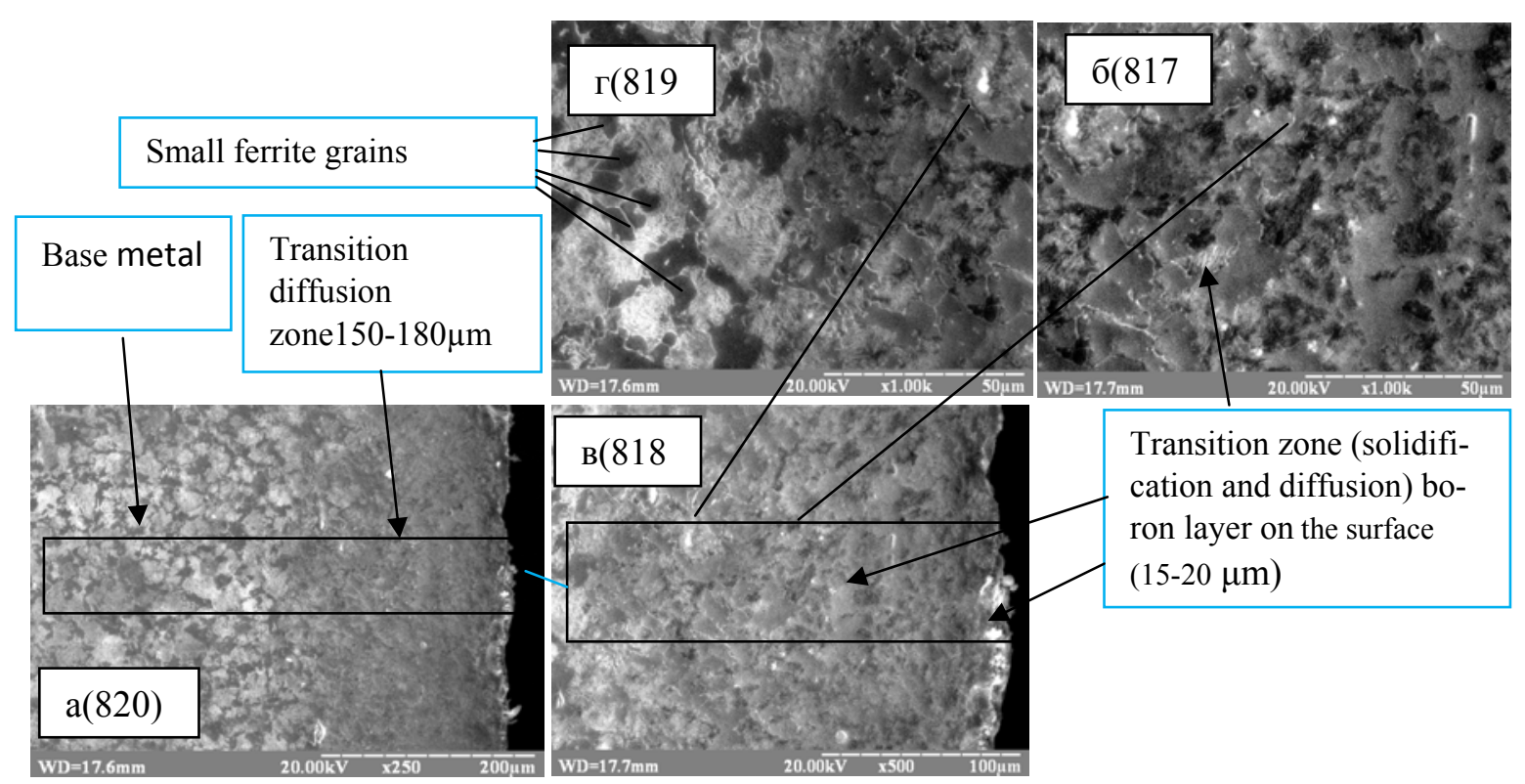

Fig. 1. Photos of the microstructure of the part surface layer of the cam sector from steel 45 


\section{Research methodology}

It is suggested to use samples of the following metals for research:

- steel 45 without treatment, NRC45;

- steel 45, surface modified with boron: - steel $45+$ Vi\%, NRC65.

In this case, to determine the parameters of friction interaction, a machine to test materials for friction and wear model SMC-2 using samples is proposed:

- for steel 45 in the form of triangles with a cylindrical outer surface, $4 \mathrm{~mm}$ thick, which is fixed in the mandrel and static;

- for other metals in the form of a disk with a diameter of $50 \mathrm{~mm}$ and a thickness of $12 \mathrm{~mm}$, which is fixed to the lower shaft of the machine and rotates.

The parameters of the molecular component are proposed to be determined in accordance with the method of work on the adhesionometer OT-1 $[12,13]$, and on the device with the use of a spherical indenter [7], which provide for measurements of the friction torque Mt when the friction coupling of spherical surfaces with planes is broken the surfaces of the samples (plates) and the radius (diameter) of the imprint projection R0 (d). However, the simulation of the friction coupling will be carried out when the disk is displaced from the disc position relative to the triangle-shaped pads at appropriate loads (Fig. 2a) with the use of the SMC-2 friction machine with the corresponding redesign of the lower shaft drive. With:

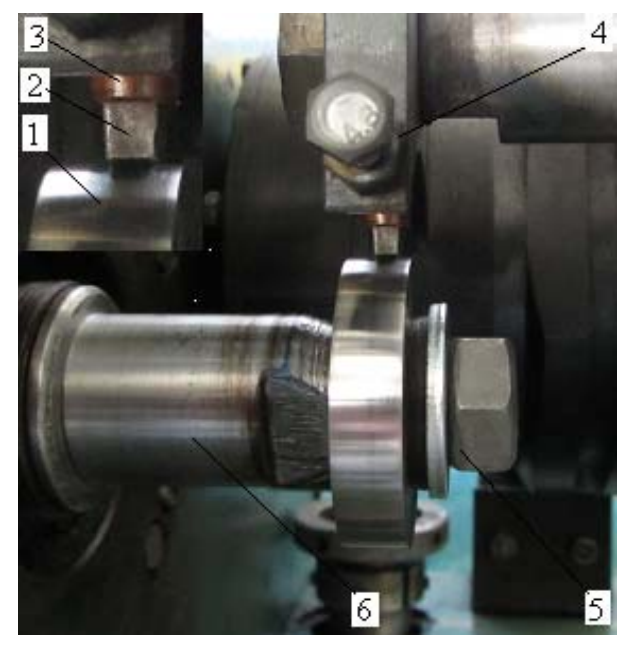

a
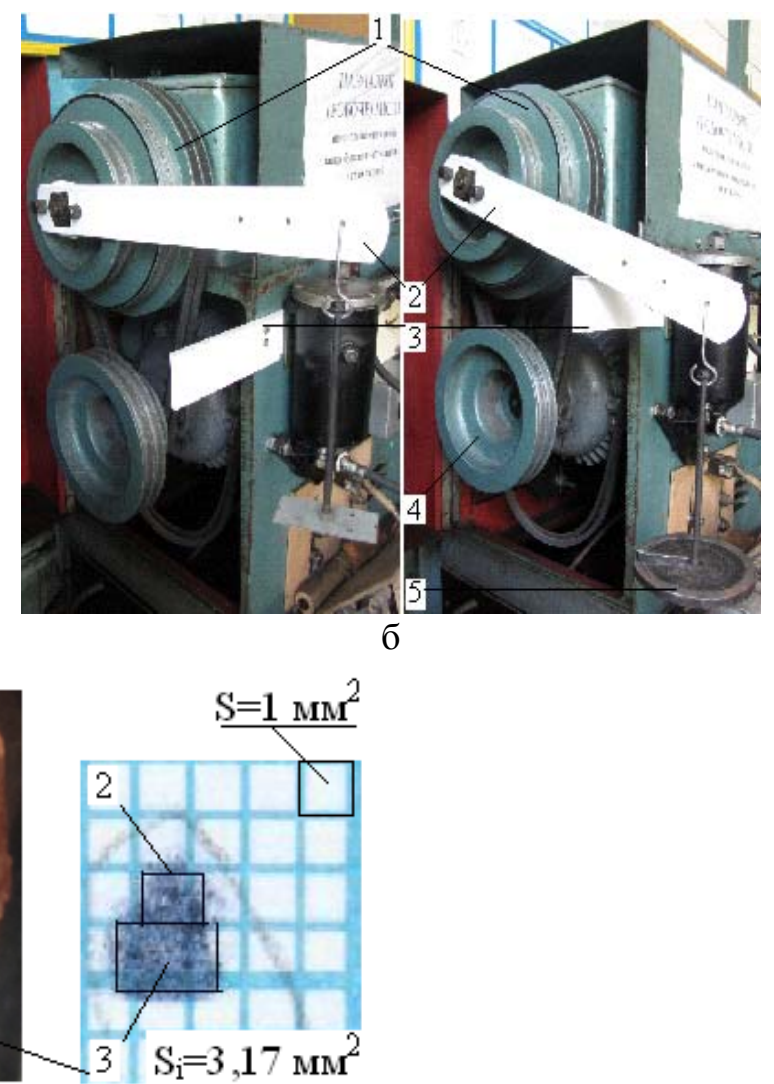

B

Fig. 2. Methodological support for measurement of displacement resistance during displacement: a - contact of model samples: 1 - disk; 2 - a shoe; 3 - additional holder of the pad; 4 - screws securing the additional holder; 5 - details of mounting the disk; 6 - the lower shaft of the friction machine SMC-2; $\mathrm{b}$ - angular loading drive of the lower shaft: 1 - the upper pulley; 2 - the cargo lever; 3 - limiter of movement of the lever of cargoes; 4 - the lower pulley; 5 - cargo; $\mathrm{C}$ - fingerprints, $\mathrm{N}=280 \mathrm{H}: 1-$ booth with boron carbide; 2,3 - perimeters of the calculated planes 
- the maximum moment of displacement will be determined by the recorder on the field of the scale tape at a fixed rotation on the angle $\alpha$ under the specified load of the lower shaft (Fig. 2 b). The weight of the load will determine the shear rate; per (Fig. 3).

- the area of interaction of the friction surfaces will be determined by the imprint on graph pa-

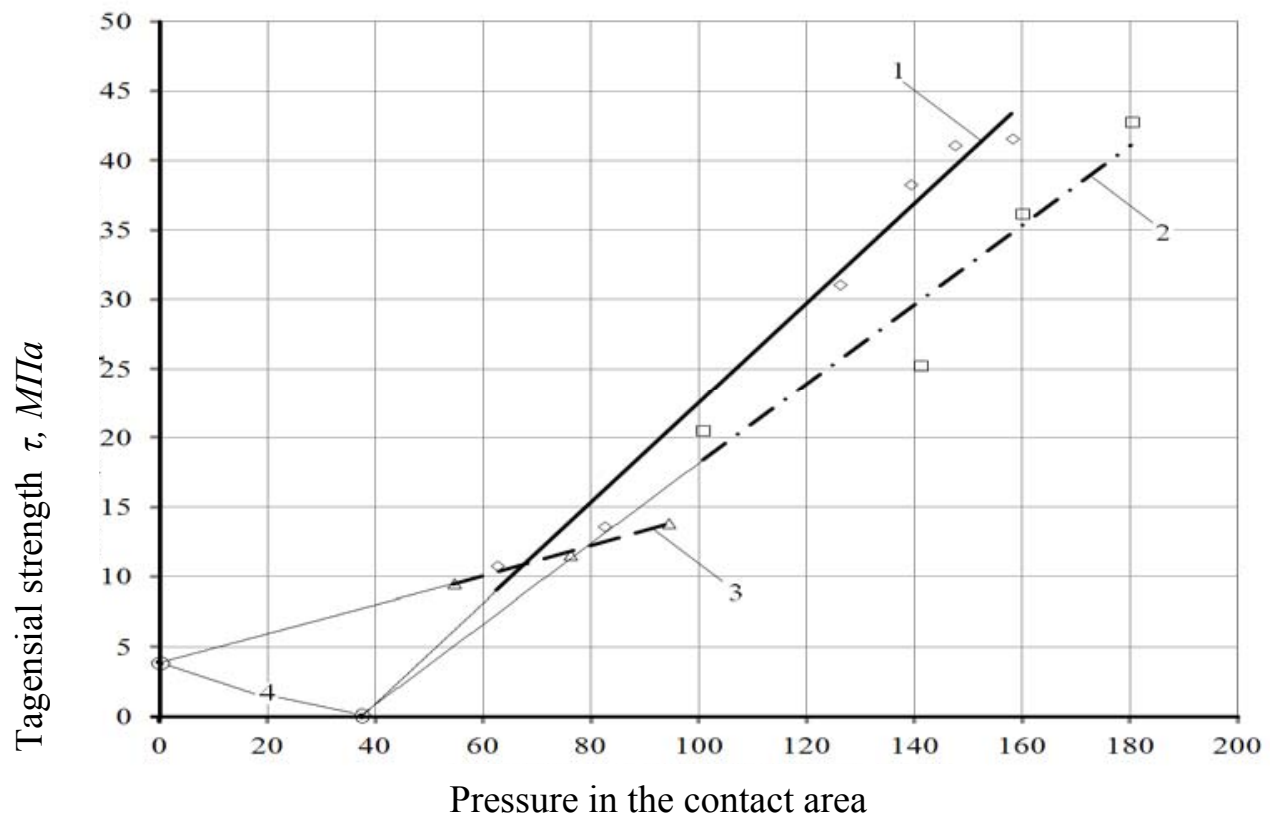

Fig. 3. Dependence of the tangential strength of adhesive bonding of non-drilled steel 45 on the pressure at a shear rate of $10.16 \pm 0.8 \mathrm{~mm} / \mathrm{s}: 1-12 \mathrm{X} 2 \mathrm{H} 4 ; 2-40 \mathrm{X} ; 3-45 \mathrm{HN} 2 \mathrm{MFA} ; 4-$ backward extrapolation points

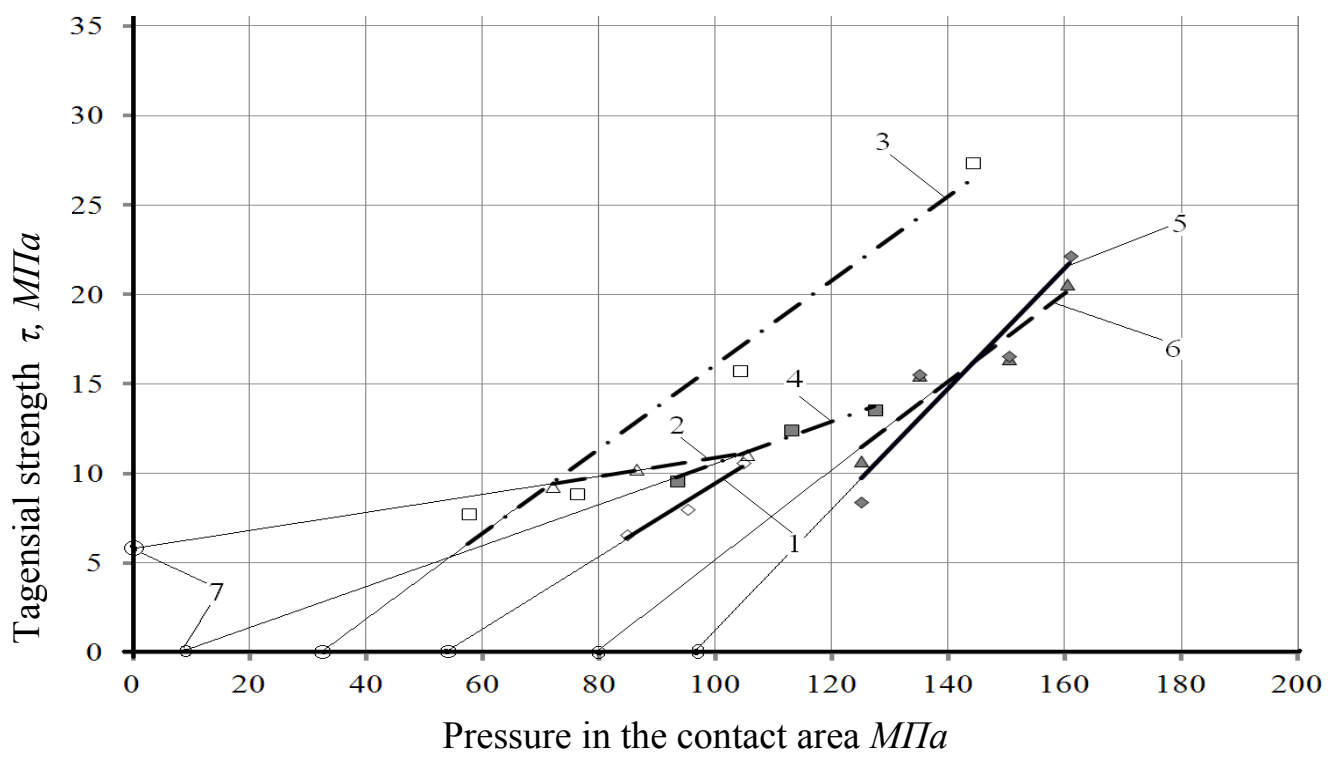

Fig. 4. Dependence of the tangential strength of the adhesive bond of the bored steel 45 on the pressure at a shear rate of $10.16 \pm 0.8 \mathrm{~mm} / \mathrm{s}: 1,2,3$ - (boron): 12X2H4; 45XN2MFA; 40X; 4,5,6 (boron carbide): 40X; 12X2H4; 45XN2MFA; 7 - points of inverse extrapolation 


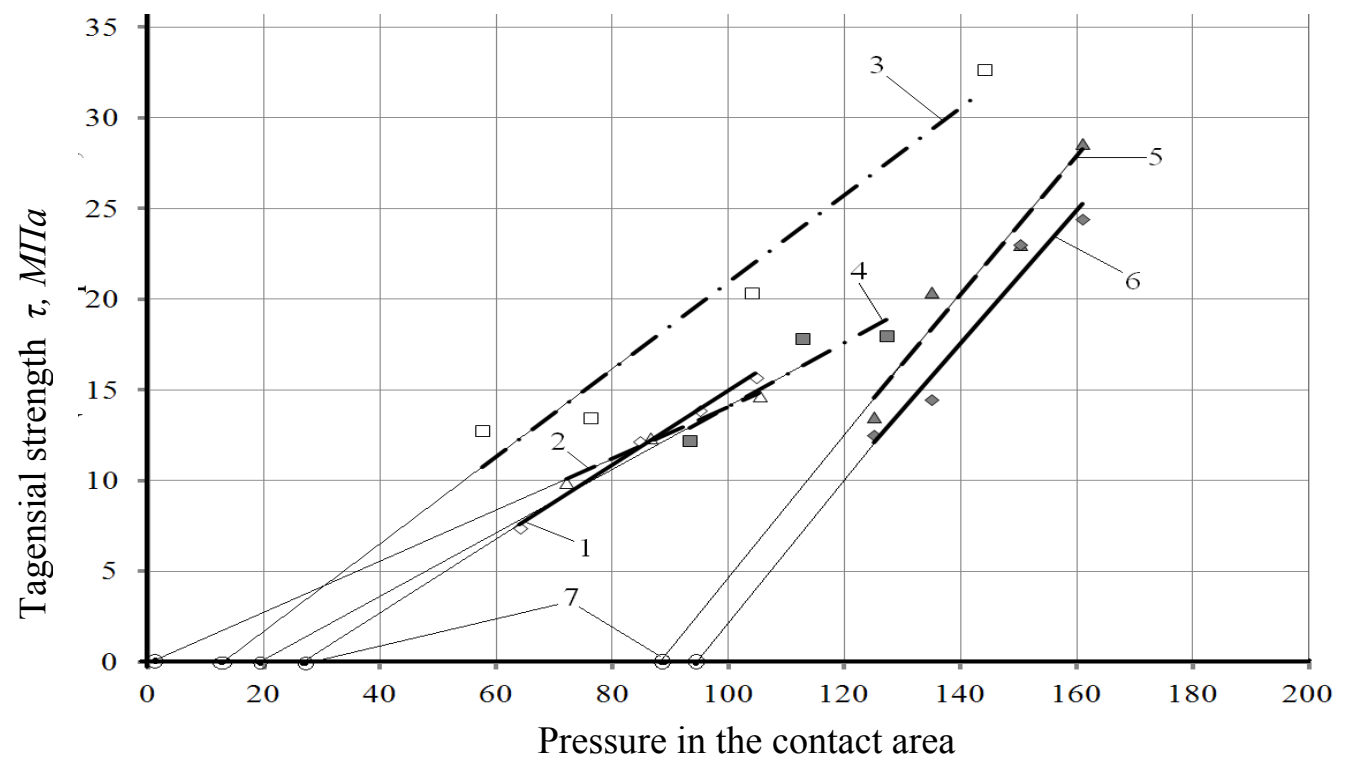

Fig. 5. Dependence of the tangential strength of the adhesive bond of the stainless steel 45 on the pressure at a shear rate of $5.08 \pm 0.6 \mathrm{~mm} / \mathrm{s}: 1,2,3-$ (boron): $12 \mathrm{X} 2 \mathrm{H} 4 ; 45 \mathrm{XN} 2 \mathrm{MFA} ; 40 \mathrm{X} ; 4,5,6$ — (boron carbide): 40X; 12X2H4; 45XN2MFA; 7 - points of inverse extrapolation

The review of the results indicates the following

Boring has a significant effect on changing the parameters of the adhesive bond. The parameter $\tau 0$ had only the tribological system of materials "45XH2MФA - steel 45", with the exception of the mode of interaction at a shear rate of $5.08 \pm 0.6 \mathrm{~mm} / \mathrm{s}$.

For other tribological systems of materials, the parameter of occured only with increasing pressure in the contacts to the corresponding values, which also differ from both the modification characteristics and the hardness of the contacting surfaces. Thus, for tribological systems of materials "12X2H4 - steel 45" and "45XH2MФA - steel 45" boring shifts the pressure values at which the adhesive bond $(\tau>0)$ begins to show toward larger values (Tabl. 1), while in the tribological system "40X steel $45 "$ on the contrary - towards smaller values except the shear rate of $5.08 \pm 0.6 \mathrm{~mm} / \mathrm{s}$. The above mentioned indicates that there are modes of contact interaction in which during the calculating it is not advisable. to take into account its molecular component, for example, the coefficient of friction.

The proposed scheme of friction "disk - shoe" firstly is due to the appropriateness of boring the subject structural elements, in this case, they are the segments of the camshafts of the internal combustion engine, and secondly by the simplification of the reproduction of displacement when using the typical test equipment.

The measurements in the following sequence were performed. The disks of the corresponding materials were fixed to the lower shaft of the friction machine. The shoes were placed in an additional holder, fixed with screws in a regular holder, which is fixed to the upper shaft of the friction machine. Further, the pad was pressed against the disk with the appropriate force by a friction machine load screw. The loads were mattered as $140 \mathrm{~N}, 185 \mathrm{H}, 230 \mathrm{H} ; 280 \mathrm{H}$. In the following, the disk was displaced by the loads 5 (Fig. 2b) and rotated to a fixed angle $\alpha$. Time spent on angular displacement determined the shear rate $-\mathrm{t} 1=0.43 \mathrm{~s} \mathrm{t} 2=1 \mathrm{~s}$. The average linear displacement of the disk was $1=4.5 \mathrm{~mm}$. At the same time, the recorder on the tribogram recorded the temporary resistance to shift by deviation from zero. The friction moment was determined by the mean statistical with the corresponding dispersions by the number of experiments $(\mathrm{n}=8)$ at two shear rates: $v 1=10.16 \pm 0.8 \mathrm{~mm} / \mathrm{s}, \mathrm{v} 2=5.08 \pm 0.6$ $\mathrm{mm} / \mathrm{s}$. The average statistical variance $\tau$ was $\mathrm{D}_{\min }=0.5 \mathrm{MPa}, \mathrm{D}_{\max }=1.13 \mathrm{MPa}$.

The adhesive bond shear strength (molecular bond shear resistance) - the tangential strength $\tau$ was determined in accordance with the expression: 


$$
\tau=\frac{M_{m}}{r \cdot S_{b}},
$$

where $M_{m}$ is the moment of shear friction, $\mathrm{Nm} ; \mathrm{r}$ is the radius of the disk, $\mathrm{m} ; \mathrm{S}_{\mathrm{b}}$ is the area of the imprint, $\mathrm{mm}^{2}$.

\section{Results of the studies and their discussion}

A graphical approximation of the averaged data in the form of linear dependencies with inverse extrapolation of the shear resistance to displacement is shown in Fig. 3-5.

In this case, the parameters of the trend lines in Excel program determine their equations and the reliability of the approximation of $\mathrm{R} 2$, the results are shown in tabl. 1 .

Table 1. Parameters of approximation of experimental data for tribological system of materials "12X2H4 - steel 45"

\begin{tabular}{|c|c|c|c|}
\hline Parameter & $\begin{array}{c}\text { Steel } 45 \\
\text { without boring }\end{array}$ & $\begin{array}{c}\text { Steel } 45 \\
\text { with boron }\end{array}$ & $\begin{array}{c}\text { Steel } 45 \\
\text { with boron carbide }\end{array}$ \\
\hline \multirow[t]{2}{*}{ Kind of equation } & $\tau=0,36 p-13,44$ & $\tau=0,19 p-10,44$ & $\tau=0,33 p-32,05$ \\
\hline & & $\tau=0,2 p-5,46$ & $\tau=0,37 p-33,73$ \\
\hline \multirow{2}{*}{$\begin{array}{l}\text { The accuracy of the ap- } \\
\text { proximation } R^{2}\end{array}$} & 0,98 & 0,96 & 0,88 \\
\hline & & 0,99 & 0,95 \\
\hline \multirow[t]{2}{*}{ Piezo coefficient $\beta$} & 0,36 & 0,19 & 0,33 \\
\hline & & 0,2 & 0,37 \\
\hline \multirow{2}{*}{$\begin{array}{l}\text { Tangential strength } \\
\tau_{0}, \mathrm{M \Pi а}\end{array}$} & $>0$ in $p \approx 37 \mathrm{MПа}$ & $>0$ in $p \approx 55 \mathrm{MПа}$ & $>0$ in $p \approx 97 \mathrm{MПа}$ \\
\hline & & $>0$ in $p \approx 27 \mathrm{MПа}$ & $>0$ in $p \approx 91 \mathrm{M \Pi а}$ \\
\hline
\end{tabular}

Note. The upper line at shear rate $v 1=10.16 \pm 0.8 \mathrm{~mm} / \mathrm{s}$, the lower line at $v 2=5.08 \pm 0.6 \mathrm{~mm} / \mathrm{s}$.

There is no obvious general mechanism between the tendency of increasing the hardness of chromium, chromium-nickel steel and the coefficient of molecular bond $\beta$ to the steel surface 45 when it is modified, since the increased hardness from $15 \mathrm{HRC}$ to $45 \mathrm{HRC}$ :

- boring causes the storage of a minimum of $\beta(0.36 ; 0.11 ; 0.28$ without treatment $)$ and $(0.19$; $0.05 ; 0.23)$

- boron carbide causes a decrease in $\beta(0.33$ - without treatment; $0.24 ; 0.11)$.

Within one tribological system of materials, the maximal values of $\beta$ are observed in the friction connection with the material of less rigidity - the system "12X2H4 - steel 45", and the modification of steel 45 leads to its decrease. This also occurs in the tribological system "40X - steel 45 " where $40 \mathrm{X}$ steel has the maximal hardness. At the same time, at a hardness of 22HRC (intermediate value) for the system "45XН2МФA - steel 45", the values of $\beta$ are generally the lowest. It is also noted that boron boron and carbide in all cases reduces the value of $\beta$ with the exception of the system "45HN2MFA - steel 45", in which it increases.

Also, there was an ambiguous effect of the shear rate on the manifestation of the adhesion parameters. Thus, for the tribological system "12X2H4 - steel 45" and "40X - steel 45", when the shear rate was reduced by almost 2 times, the value of $\beta$ did not change significantly, however, as in the system "45ХН2МФА - steel 45" it increased in 2.8 times when saturated with boron, and boron carbide is in 1.58 times. In regard to pressures at which $\tau>0$, they are essentially:

- decrease when boron saturated in 2.46 times for the system "40X - steel 45", 2 times for "12X2H4 - steel 45";

- increase when boron saturated with carbide in 1.9 times for "40X - steel 45 ".

\section{Conclusions}

Introduced approaches to modeling the shear resistance under changes in normal loads and velocity of movement have been proposed, which made it possible to determine the nature of the effect of boring on the manifestation of the adhesion properties of the proposed materials. It is established that only $45 \mathrm{XH} 2 \mathrm{M} \Phi A$ steel according to the conditions and modes of force, kinematic loading indi- 
cates the presence of a parameter of tangential strength $\tau 0$ from steel 45 , in other experimental tribological systems of materials preliminary compressive efforts are required.

It is determined that in order to further reveal the mechanisms of adhesion bond formation, it is necessary to establish and take into account the topographies of the microhardness of the phase components of the contact interaction zones.

\section{References}

[1] Fransenyuk, I.V., \& Fransenyuk, L.V. (2004). Albom microstructur chuguniv, staley, tsetnih metaliv ta yih splavsiv [Product innovative police].Moskva: Akademkniga [in Rosiya].

[2] Malinov, L.S.(2012). Diferentsialnie obrobki splaviv dlya povisheniya ih svoystv-perspektivnoye napravlenie [Novi materialy i tehnologyi $v$ metalurgii i mashinobuduvanni]Naukoviy chshurnal,2, 50-56.[in Ukrainian].

[3] Devoyno, O.G. (2001). Tehnologii formirovaniya iznosostoykih pokritiy s pomochshyu lazernoy obrobotki. Minsk: UP Tehnologiya [in Belorusiya].

[4] Cherneta, O.G., \& Babko I.O., \& Chaldishev Ye.V. (2014) Doslidchshennya tehnologichnih sposobiv formuvannya znosostiykih pokritiv na osnovi lazernoyi obrobki [Perspektivni tehnologii ta priladi] Zbirnik naukovih prats, 5(2) 171-176.[in Ukrainian].

[5] Cherneta, O.G., \& Suhomlin, \& Volochshyk, R.G., \& Sereda, B.P. (2017) Doslidchshennya mikrostrukturi znoshennyh detaley avtomobiliv iz staly 45 pri vidnovlenny $i$ bagatokratniy termichniy obrobtsy [Perspektivni tehnologii ta priladi] Zbirnik naukovih prats, 10(1) 212-216.[in Ukrainian].

[6] Cherneta, O.G., \& Suhomlin, V.I., \& Korobochka, O.M. (2017) Analiz transformatsii mikrostrukturi poverhnevogo sharu iz staly $45 v$ zalechshnosty vid tehnologichnih metodiv obrobki [Perspektivni tehnologii ta priladi] Zbirnik naukovih prats, 11(2) 147-152. [in Ukrainian].

[7] Skornyakov, E.S., \& Cherneta, O.G., \& Volochshyk, R.G. (2015). Vidnovlennya kulachkiv rozpodilnih valiv elektrodugovoyu naplavkoyu [Perspektivni tehnologii ta priladi] Zbirnik naukovih prats, 7(2) 113-116. [in Ukrainian].

[8] Cherneta, O.G., \& Kubich, V.I., \& Skornyakov, E.S. (2017). Analiz mehanizmov uprochneniya sredneuglerodistih stalel [Perspektivni tehnologii ta priladi] Zbirnik naukovih prats, 11(2) 142146. [in Ukrainian].

[9] Cherneta, O.G., \& Suhomlin, V.I., \& Kalinichenko, S.V. (2019) Doslidchshennya vidnovlenogo poverhnevogo sharu detaley iz stali 45 zmitsnyuchoyu obrobkoyu na znosostiykosty [Matematichne modelyuvannya] Naukoviy chshurnal, 1(40) 194-199. [in Ukrainian].

[10] Cherneta, O., \& Kubich, V., \& Volochshuk, R., \& Sasov, O., \& Korzhavin, Yu. (2018). Condition for the formation of wear-resistant structures when strengthening the surface layers of parts [International Journal of Engineering Technology], 7(4.3), 76-80.

[11] Cherneta, O., \& Kubich, V., \& Volochshuk, R., \& Averyanov, V., \& Shmatko, D. (2018). Strengthening of the restored surface layer of steel parts 45 by laser boribg [International Journal of Engineering Technology], 7(4.3), 71-75.

[12] Kragelskiy, I.V., \& Dobichin, M.N., \& Kombalov, V.S. (1977) Osnovi raschetov na trenie i uznos M.: Inchshenerna mehanika [in Rosiya].

[13] Semenov, V.I., \& Shuster, L.S., \& Chertovkih, S.V., \& Raab, G.I. (2005). Vliyanie kompleksnogo parametra plastichnostu na kontaktnoye treniye I strukturu materialov na prognosirovanie adgezionnih svyazey. [Trenie i iznos](Vols.26(1))74-79. 


\title{
ДОСЛІДЖЕННЯ НА ЗНОСОСТІЙКІСТЬ ПОВЕРХНЕВОГО ШАРУ КУЛАЧКА РОЗПОДІЛЬНОГО ВАЛУ ДВИГУНА ІЗ СТАЛІ 45 ПІСЛЯ ЗМЩНЮЮЧОЇ ОБРОБКИ
}

\author{
Чернета О.Г., Кубич В.І., Щербіна М.А., Аверьянов В.С., Шматко Д.3.
}

\section{Реферат}

Контактна взаємодія робочих поверхонь металів при здійснені передачі та перетворення рухів здійснюється з втратами на тертя, які визначаються молекулярною та механічною складовою. Це стосується і поверхонь, які модифіковані легуючими елементами, процентній вміст яких впливає на термодинамічний потенціал поверхневих та при поверхневих шарів. Визначення впливу поверхневого борування сталі 45 на зміну параметрів адгезійного зв'язку $\tau_{0}$ та $\beta$ з хромо, хромо-нікелевими сталями з варіантною твердістю поверхневих шарів при моделюванні зсувного опору, де на першому етапі пропонується проведення порівняльного дослідження без мастильних матеріалів. При застосуванні технології поверхневого насічення бором виходить, що варіантність механічних властивостей сталі 45 і прояв параметрів молекулярної складової як в умовах мащення, так й без нього при контактної взаємодії з поверхневими шарами інших металів 3 варіантною твердістю буде мати різні значення. Для відновлення робочої поверхні кулачків с сталі 45 використовували електроди ОЗШ-3 з наступним хімічним складом (С $0,4 \% ; \mathrm{Mn}-0.5 \%$; $\mathrm{Si}-1.9 \% ; \mathrm{Cr}-9.9 \%$; S - 0.013\%; Р - 0.021\%). В перехідній зоні залишковий аустеніт трансформується у ферит з утворенням двох фаз: часток фериту (темні каскади) i фази «бор + вуглець» - карбід бору (білі вкраплення). Параметри молекулярної складової запропоновано визначати у відповідності з методикою роботи на адгезіометрі ОТ-1 та на пристрої із застосуванням сферичного індентора, які передбачають виміри моменту тертя $\mathrm{M}_{\mathrm{T}}$.

Момент тертя визначався середнім статистичним з відповідними дисперсіями за кількістю дослідів ( $\mathrm{n}=8)$ при двох швидкостях зсуву: $v_{1}=10,16 \pm 0,8$ мм/с, $v_{2}=5,08 \pm 0,6$ мм/с. Середня статистична дисперсія $\tau$ мала значення $\mathrm{D}_{\min }=0,5 \mathrm{MПа}, \mathrm{D}_{\max }=1,13 \mathrm{MПа}$.

Борування суттєво впливає на зміну параметрів адгезійного зв'язку. Параметр $\tau_{0}$ мала тільки трибологічна система матеріалів «45ХН2МФА - сталь $45 »$, за виключенням режиму взаємодії при швидкості зсуву 5,08 $\pm 0,6 \mathrm{mм} / \mathrm{c}$.

Для інших трибологічних систем матеріалів параметр $\tau_{0}$ мав місце тільки при збільшені тиску у контакти до відповідних значень, які також відрізняються як від характеристик модифікування, так і від твердості контактуючих поверхонь.

Також, встановлено неоднозначний вплив швидкості зсуву на прояв параметрів адгезійного зв'язку. Так для трибологічної системи «12Х2Н4 - сталь 45» та «40X - сталь 45» при зменшені швидкості зсуву майже в 2 рази значення $\beta$ суттєво не змінювалось, проте як у системі «45ХН2МФА - сталь 45» збільшувалось при насичені бором в 2,8 рази, а карбідом бору в 1,58 рази. Стосовно тисків, при яких $\tau>0$, то вони суттєво: - зменшуються при насичені бором в 2,46 рази для системи «40X - сталь $45 »$, в 2 рази для «12X2Н4 - сталь $45 » ;$ - збільшуються при насичені карбідом бора в 1,9 рази для « $40 \mathrm{X}$ - сталь $45 »$.

\section{Література}

1. Франценюк И.В., Франценюк Л.И. Альбом микроструктур чугунка, стали, цветных металлов и их сплавов. М.: ИКЦ «Академкнига», 2004. 192 с.

2. Малинов Л.И. Дифференцированные обработки сплавов для повышения их свойств - перспективное направление в материаловедении. Нові матеріали і технологї̈ в металургї̈ та машинобудуванні. ЗНТУ. 2012.№2'. С.50-56.

3. Девойно О.Г. Технологии формирования износостойких покритий с помощью лазерной обработки. Минск ; УП «Технология», 2001. 273 с.

4. Чернета О.Г., Бабко І.О., Чалдишев С.В. Дослідження технологічних способів формування зносостійких покриттів на основі лазерної обробки. Перспективні технології та прилади. ЗНП ЛНТУ. 2014.№5(2). С. 171-176. 
5. Чернета О.Г., Сухомлін В.І., Волощук Р.Г., Середа Б.П. Дослідження мікроструктури зношених деталей автомобілів із сталі 45 при відновленні і багатократній термічній обробці. Перспективні технології та прилади. ЗНП ЛНТУ. 2017.№10(1). С. 212-216.

6. Чернета О.Г., Сухомлін В.І., Коробочка О.М. Аналіз трансформації мікроструктури поверхневого шару із сталі 45 в залежності від технологічних методів обробки. Перспективні технології та прилади. ЗНП ЛНТУ. 2017.№11(2). С. 147-152.

7. Скорняков Е.С., Чернета О.Г., Волощук Р.Г. Відновлення кулачків розподільних валів електродуговою наплавкою. Перспективні технологї та прилади. ЗНП ЛНТУ. 2015.№7(2). C. 113-116.

8. Чернета О.Г., В.И. Кубич, Скорняков Э.С. Анализ механизмов упрочнения среднеуглеродистих сталей. Перспективні технології та прилади. ЗНП ЛНТУ. 2017.№11(2). С. 142-146.

9. Чернета О.Г., Сухомлін В.І., Калініченко С.В. Дослідження відновленого поверхневого шару деталей із сталі 45 із зміцнюючою обробкою на зносостійкість. Науковий журнал «Математичне моделювання». ДДТУ. 2019. № 1 (40). С. 194-199.

10. Cherneta O., Kubich V., Voloshchuk R., Sasov A., Korzhavin Yu.. Condition for the formation of wear-resistant structures when strengthening the surface layers of parts. International Journal of Engineering Technology. 2018. 7(4.3). P. 76-80.

11. Cherneta O., Kubich V., Voloshchuk R., Averyanov V., Shmatko D. Strengthening of the restored Surface layer of steel parts 45 by laser boribg. International Journal of Engineering Technology. 2018. 7(4.3). P. 71-75.

12. Крагельский В.И., Добучин В.С., Комбалов М.Н. Основы расчетов на трение и износ./ М. Инженерная механика, 1977. 526 с.

13. Семенов В.И., Шустер Л.С., Чертовских С.В., Рааб Г.И. Влияние комплексних параметров пластичності на контактное трение и структуру материалов на прогнозирование адгезионных свіязей. Трени и износ. 2005. №26(1). С. 74-79. 